\author{
Review Article \\ www.ijrap.net (ISSN:2229-3566)
}

\title{
ROLE OF PANCHAKARMA IN THE MANAGEMENT OF ANKYLOSING SPONDYLITIS: A REVIEW
} Anisha M. S. ${ }^{1 *}$, Seetha Devi P. ${ }^{2}$, Deepthi C. R. ${ }^{1}$

${ }^{1}$ PG Scholar, Department of Panchakarma, JSS Ayurveda Medical College, Mysore, India

${ }^{2}$ Reader and Head, Department of Panchakarma, JSS Ayurveda Medical College, Mysore, India

Received on: 05/05/20 Accepted on: 22/06/20

\author{
*Corresponding author \\ E-mail: anisha.ms30gmail.com
}

DOI: $10.7897 / 2277-4343.1104120$

\begin{abstract}
Ankylosing spondylitis is an auto immune, systemic rheumatic disease, meaning it affects the entire body. A type of arthritis in which there is long term inflammation of the joints of the spine. Typically, the joints where the spine joins the pelvis are affected. Occasionally other joints such as the shoulders or hips are involved. Modern science has very limited option to treat Ankylosing spondylitis. So there is a growing interest towards Ayurvedic system of medicine for the treatment of Ankylosing spondylitis. Panchakarma procedures like Virechana, Basti, Nasya, etc play a significant role in the management of Ankylosing spondylitis. Hence this article highlights the importance of Panchakarma in the management of Ankylosing spondylitis.
\end{abstract}

Keywords: Ankylosing Spondylitis, Gambhira Vatarakta, Panchakarma

\section{INTRODUCTION}

Ankylosing spondylitis is an auto immune, chronic inflammatory arthritis with a predilection for the sacroiliac joints and spine. Ankylosing spondylitis is a gradually progressive condition characterised by progressive stiffening and fusion of axial skeleton. The extra-articular structures are also frequently involved $^{1}$. It is more common among males than females; the ratio is 4:1. The presence of the HLA-B27 gene is seen among 90\% people with Ankylosing spondylitis. It commonly occurs among younger people between ages 17 and 45 . It can affect children and elderly. ${ }^{2}$ The rate of Ankylosing spondylitis in Asia is 16.7 per 10,000 people. Its aetiology and pathogenesis are not yet fully understood. The presentation of Gambhira Vatarakta reveals that most of the features of Ankylosing Spondylitis mimic's the Lakshanas of Gambhira Vatarakta. So, Ankylosing spondylitis can be managed by adopting various Panchakarma procedures.

\section{Ankylosing Spondylitis}

\section{Causes}

The tendency to develop Ankylosing Spondylitis is believed to be genetically inherited, i.e. about $90 \%$ of people with Ankylosing Spondylitis are HLAB27 positive and with these the environmental pathogens also play an important role in developing Ankylosing Spondylitis. ${ }^{2}$

\section{Pathology}

Early in the process, there is inflammatory granulation tissue at the junction of annulus fibrosus and vertebral bone, leading to erosion of outer annular fibers; they are eventually replaced by boney formation i.e. the bony syndesmophytes, the growth is continued by causing endochondral ossification i.e. bridging of adjacent vertebral bodies. The Ascending progression of this process leads to Bamboo Spine. ${ }^{2}$

\section{Clinical Features}

Ankylosing Spondylitis is a gradually progressive condition over several years. The initial symptoms is usually dull pain, insidious in onset, felt deep in the lower lumbar or gluteal region, accompanied by morning stiffness that improves with activity and returns following inactivity. Nocturnal exacerbation of pain that forces patient to rise and move around may be frequent. Bony tenderness (Enthesitis) may accompany back pain and stiffness or may be a predominant complaint, usually asymmetric and can occur at any stage of the disease. As the disease progresses, loss of spinal mobility, with limitation of anterior and lateral flexion and extension of the lumbar spine and of chest expansion is noted. The disease tends to ascend the spine slowly and eventually after several years, the whole spine may be affected, also causes extraarticular symptoms, peripheral arthritis and reduced quality of life. 


\section{Diagnostic Criteria}

Table 1: Diagnostic criteria of Ankylosing Spondylitis

\begin{tabular}{|c|}
\hline Modified New York criteria (1984) \\
\hline Criteria \\
\hline Low back pain at least 3 months duration improved by exercise and not relived by rest. \\
\hline Limitation of lumbar Spine in Sagittal and frontal planes \\
\hline Chest expansion decreased relative to normal values for age and sex \\
\hline Bilateral Sacroiliitis grade 2 to 4 \\
\hline Unilateral Sacroiliitis grade 3 to 4 \\
\hline Definite Ankylosing Spondylitis \\
\hline Unilateral grade 3 or 4,or bilateral grade 2 to 4 Sacroiliitis and any clinical criterion. $^{2}$ \\
\hline
\end{tabular}

\section{Management}

Treatment includes medication, exercise and surgery. NSAIDs and analgesics are often effective in relieving symptoms but do not alter the course of the disease. ${ }^{2}$

\section{Ankylosing Spondylitis in Ayurveda}

Ankylosing spondylitis can be correlated to Gambhira Vatarakta. All features of Gambhira Vatarakta may not mimic the features of Ankylosing Spondylitis. In Gambhira Vatarakta there will be involvement of Mamsa, Asthi, Sira Snayu, in later stages of the disease there will be formation of deformities. ${ }^{3}$ Generally people who are Sukumara, who consume Mishthaanna Bhojana, Sukha Bhojana (sedentary life style) with Nidana like increased intake of Lavana, Amla, Katu, Kshara, Asnigdha, Ushna, Ajeerna Bhojana, Dadhi, Kulatha, Viruddha Ahara, Adhyashana and one who do not undergo proper Shodhana will lead to Rakta Dushti. Simultaneously increased Vata Dosha due to Ati Yaana, Vegadharana etc reasons, it gets obstructed by Dushita Rakta hence leading to Vatarakta ${ }^{4}$.

Table 2: Probable co-relation of features of Gambhira Vatarakta with ankylosing spondylitis

\begin{tabular}{|c|c|}
\hline Gambhira Vatarakta & Ankylosing Spondylitis \\
\hline Stabdatha (Stiffness) & Morning stiffness and stiffness. Common sites: Cost sternal junction, spinous process, Ischial \\
& tuberosities, heels etc. \\
\hline Toda / Ruk (Pain) & Pain in low back, Cost sternal junction, spinous process, Ischial tuberosities, heels etc. \\
\hline Atyanta-Vaikruta (Deformities) & Kyphosis, lordosis \\
\hline Antar Bhrusha Arti (excruciating pain) & Nocturnal exacerbation of pain that forces patient to rise and move around may be frequent \\
\hline
\end{tabular}

Hence, the line of management of Gambhira Vatarakta has to be adopted.

\section{Role of Panchakarma}

\section{Deepana and Pachana}

It is carried out as Purva Karma to Shodhana Chikitsa for Ama Pachana and Agni Deepana with Tikta, Katu Rasa and Ruksha Guna Pradhana drugs according to Rogi and Roga Bala.

Table 3: Deepana and Pachana Dravya, Dose and Anupana

\begin{tabular}{|c|l|c|c|}
\hline Dosha & \multicolumn{1}{|c|}{ Dravya } & \multicolumn{1}{|c|}{ Dose } & Anupana \\
\hline Vataja & Ajmodadi Choorna & $3-6$ grams before food & Ushna Jala \\
\hline Pittaja & $\begin{array}{l}\text { 1. Jeerakadi Choorna } \\
\text { 2. Drakshadi Choorna }\end{array}$ & $\begin{array}{l}3-6 \text { grams before food } \\
3 \text { to } 6 \text { grams before food }\end{array}$ & Honey / Ushna Jala \\
& & & Honey /Ushna Jala \\
\hline Kaphaja & $\begin{array}{l}\text { 1. Hinguwashtaka Choorna } \\
\text { 2. Lavana Bhaskara } \\
\text { Choorna }\end{array}$ & TID before food & \\
& $\begin{array}{l}\text { 3. Agnitundi Vati } \\
\text { 4. Chitrakadi Vati }\end{array}$ & & \\
\hline
\end{tabular}

\section{Swedana}

In Ama Avastha (Aruchi, Gaurava) if Stambha, Shoola are present then Ruksha Sweda should be the first line of management.

Table 4: Ruksha Sweda and drugs used

\begin{tabular}{|c|c|c|}
\hline S. No. & Ruksha Sweda & Drugs \\
\hline 1. & Parisheka & Dhanyamala, Dashmoola Kashaya \\
\hline 2. & Choorna Pinda Sweda & Kolakulathadi Choorna, Triphala Choorna \\
\hline
\end{tabular}

In Nirama Avastha,if Stambha, Shoola, Shotha are present then Snigdha Sweda should be done. 
Table 5: Snigdha Sweda and its mode of action

\begin{tabular}{|c|c|}
\hline Snigdha Sweda & Mode of action \\
\hline Patra Pinda Sweda & Vatahara, Shoolahara \\
\hline Jambira Pinda Sweda & Vatakaphahara, Shoolahara \\
\hline Kukutanda Sweda & Balya, Stambha hara \\
\hline Prushta Basti & Shoolahara, Sthanika Chikitsa \\
\hline Shastika Shali Pinda Sweda & Bhrumhana, Vatahara, Balya \\
\hline
\end{tabular}

\section{Snehana}

Both Shodhananga Sneha as well as Shamananga Sneha was indicated in Vatarakta. As Poorva Karma to Virechana, patient is subjected to Shodhananga Sneha.

Table 6: Dosha predominant and Sneha

\begin{tabular}{|c|c|}
\hline Dosha predominant & Sneha \\
\hline Vata Pradhana Vatarakta & Shadhphala Ghrita, Madhuyashtyadi Ghrita, Dhanvantara Ghrita \\
\hline Pitta Pradhana Vatarakta & Mahatiktaka Ghrita, Panchatiktaka Ghrita, Shatavari Ghrita \\
\hline Kapha Pradhana Vatarakta & Guggulu Tiktaka Ghrita, Madhuyashtyadi Taila, Guduchyadi Ghrita \\
\hline
\end{tabular}

\section{Virechana}

Table 7: Virechana Dravyas, Anupana and Dosage

\begin{tabular}{|c|c|c|}
\hline \multicolumn{1}{|c|}{ Virechana Dravya } & Anupana & Dosage \\
\hline $\begin{array}{l}\text { Mridu Virechana with } \\
\text { Eranda Taila }\end{array}$ & $\begin{array}{c}\text { Ksheera / Ushna } \\
\text { Jala. }\end{array}$ & $\begin{array}{c}\text { Nitya Virechana }-10-15 \mathrm{ml} \\
\text { at night }\end{array}$ \\
\hline $\begin{array}{c}\text { Amruta + Eranda Taila } \\
\text { Sneha Purva Shodhana } \\
\text { Trivita lehya }\end{array}$ & For 3 days & Draksha Kashaya \\
& & $40-60$ grams \\
\hline
\end{tabular}

\section{Basti}

Vatarakta is better treated by Basti Chikitsa. ${ }^{5}$ In case of all types of Vatarakta, especially in Vata Pradhana Vatarakta, Ksheera Basti or Guduchyadi Ksheera Basti is advised ${ }^{6}$.

\section{Anuvasana Basti}

Table 8: Drugs used in Anuvasana Basti

\begin{tabular}{|c|c|}
\hline Ghrita/taila & Gunas \\
\hline Panchatikta Ghrita & Tikta Rasa, Katu Vipaka, Sheeta -Virya, Ruksha Guna Pradhana, Vatapitta hara \\
\hline $\begin{array}{c}\text { Madhuyashtyadi } \\
\text { Taila }\end{array}$ & Madhura Rasa, Madhura Vipaka, Sheeta Virya, Pittahara \\
\hline Balaguduchyadi Taila & Madhura Tikta Rasa Pradhana, Madhura Vipaka, Sheeta Virya, Vatapitta hara \\
\hline Shatavari Ghrita & $\begin{array}{c}\text { Madhura Rasa, Sheeta-Virya, } \\
\text { Madhura-Vipaka, Pittahara }\end{array}$ \\
\hline Sukumara Ghrita & $\begin{array}{c}\text { Kashaya Madhura, Tikta-Rasa, Katu-Vipaka ,Ushna -Virya, Ruksha and Laghu Guna, Vata } \\
\text { Pittahara }\end{array}$ \\
\hline
\end{tabular}

\section{Niruha Basti}

Table 9: Niruha Basti in Ankylosing Spondylitis

\begin{tabular}{|c|c|c|}
\hline Basti & Contents & Basti Kala \\
\hline $\begin{array}{l}\text { Ksheera Basti } \\
\text { Panchatikta } \\
\text { Ksheera Basti }\end{array}$ & $\begin{array}{c}\text { Madhu - } 50 \mathrm{ml} \text {, Saindhava - } 10 \text { grams, Panchatikta Guggulu Ghrita }-80 \mathrm{ml} \\
\text { Shatpushpa Kalka - } 30 \text { grams, Dashmoola Kashaya }-250 \mathrm{ml} \\
\text { Go Ksheera }-250 \mathrm{ml}\end{array}$ & Yoga Basti or Kala Basti \\
\hline $\begin{array}{l}\text { Guduchyadi } \\
\text { Yapana Basti }\end{array}$ & $\begin{array}{c}\text { Madhu }-50 \mathrm{ml} \text {, Yashtimadhu Taila }-100 \mathrm{ml} \\
\text { Putoyavanyadi Kalka - } 10 \text { grams, Guduchi Siddha Ksheera Paka - } 500 \mathrm{ml}\end{array}$ & $\begin{array}{l}\text { Yoga Basti or Kala Basti } \\
\text { Yoga Basti or Kala Basti }\end{array}$ \\
\hline Ardhamatrika Basti & $\begin{array}{c}\text { Madhu - } 2 \text { Pala, Saindhava Lavana - } 1 \text { Karsha } \\
\text { Sneha - } 2 \text { Pala, Shatpushpa Kalka }-1 \text { Karsha } \\
\text { Dashmoola Kashaya - Madanphala - } 1\end{array}$ & Yoga Basti or Kala Basti \\
\hline $\begin{array}{c}\text { Mustadi Yapana } \\
\text { Basti }\end{array}$ & $\begin{array}{l}\text { Madhu - } 25 \mathrm{ml} \text {, Saindhava Lavana: } 5 \mathrm{~g} \text {, Ashwagandha Taila: } 50 \mathrm{ml} \\
\text { Panchatikta Ghrita } 25 \mathrm{ml} \text {, } \\
\text { Ksheerpaka of Mustadi Yapana Basti Kwath Choorna: } 300 \mathrm{ml} \\
\text { Mamsa Rasa (goat femur bone marrow): } 50 \mathrm{ml}\end{array}$ & Kala Basti \\
\hline
\end{tabular}

\section{Nasya}

After Parihara Kala of Basti, Nasya Karma has to be adopted. Karpasasthyadi Taila, Anutaila or Shatbindu Taila can be used for Nasya. Dose is 4 Bindu each nostril for 7 days. Nasya helps in alleviating the diseases above Supraclavicular region such as Greeva Stambha (stiffness of neck) and Hanugraha (stiffness of jaw). 


\section{Raktamokshana}

Prior to Rakta Mokshana certain measures like Snehana, Mridu Virechana and Basti should be followed. In Gambhira Vatarakta Siravyadha is indicated. Raktamokshana by the Jalaukavacarana method is preferred if the affected site exhibits symptoms like Daha and Shoola .

\section{Bahirparimarjana Chikitsa}

It is the external purificatory measures like Abhyanga, Sweda and Lepa etc. ${ }^{7}$

Table 10: Bahirparimarjana Chikitsa

\begin{tabular}{|c|ll|}
\hline Chikitsa & \multicolumn{1}{|c|}{ Drugs used } \\
\hline Avagaha & \multicolumn{1}{|c|}{ Dashmoola Kashaya, Guduchi Kashaya } \\
\hline Lepa & 1. & Dashanga Lepa \\
& 2. & Triphala Lepa \\
& 3. & Saindhava Lavana + Eranda Taila + Marma Gulika \\
\hline Abhyanga & \multicolumn{2}{|c|}{ Madhuyashtyadi Taila, Murchita Tila Taila } \\
\hline
\end{tabular}

\section{Guduchi Prayoga}

Guduchi in the form of Swarasa, Kalka, Choorna, Kwatha can be administered in Vatarakta ${ }^{8}$ Guduchi should administered with Guda in conditions of Vata, with Sita in conditions of Pitta, with Madhu in conditions of Kapha. In severe condition it should be administered with Eranda Taila. ${ }^{9}$

\section{DISCUSSION}

Cardinal features of Ankylosing spondylitis are stiffness, deformity and restricted range of movement. When stiffness is produced due to Vata which may be associated with Ama or Kapha, the Ruksha therapies are adopted like Ruksha Pottali Sweda, Dashmoola Kashaya Seka, Dhanyamala Dhara and Alepa. After Rukshana and in Nirama Avastha, Shodhananga and Shamananga Sneha can be adopted. Mridu Virechana prevents the aggravation of Vata in the Vatarakta. Either classical Virechana or Mridu Shodhana for 3 days can be adopted. Snigdha Virechana reduces the Stabdhata and as the axial skeleton is mainly involved it is a Madhya Sharira Vata Vyadhi, Virechana is the choice of treatment. Tikta nourishes the Asthi as its Ruksha and when it is given with Eranda Taila or Ghrita it causes Shamana of Vata. Tikta Rasa is the best for treating at the Dhatwagni level, specifically for Asthi dhatu, so Amruta is the choice of drug. Amruta acts as Rasayana, its Balya and Deepaniya. Tikta Ksheera Bastis are best in the Asthiashrutha Vyadhi.

\section{CONCLUSION}

Ankylosing Spondylitis is not mentioned as separate entity in the Ayurvedic classical texts. But considering the symptoms and the cause, disease can be approached with the concept of Gambhira Vatarakta. After assessing the associative Doshas and Ama status if any; the Shodhana should be planned according to the Avastha, along with administration of Shamana Aushadhis and Pathya

\section{REFERENCES}

1. Christopher R. Edwards, Ian A.D. Bouchier, Christopher Haslett, Edwin Chilvers, editors, Davidson's Principles and Practice of medicine, $7^{\text {th }}$ ed. UK, Pearson Professional Publications; 1995. p. 1440, 1105.
2. Mark Strachan, Richard Hobson, Stuart H. Ralston, Ian D. Penman, editors, Davidson's Principles and Practice of medicine, $23^{\text {rd }}$ ed UK, Elsevier Health Publications; 2018. p. 1440, 1106-1107.

3. Agnivesha, Charaka Samhita with Ayurveda Dipika commentary of Chakrapani, Edited by Vaidya Yadavji Trikamji Acharya, Chaukhambha Surbharati Prakashan, Varanasi, reprint; 2008. p. 738, Sutra Sthana, Chapter 29, verse $21-23$; p. 821.

4. Agnivesha, Charaka Samhita with Ayurveda Dipika commentary of Chakrapani, Edited by Vaidya Yadavji Trikamji Acharya, Chaukhambha Surbharati Prakashan, Varanasi, reprint; 2008. p. 738, Sutra Sthana, Chapter 29, verse $5-15$; p. 811-813.

5. Agnivesha, Charaka Samhita with Ayurveda Dipika commentary of Chakrapani , Edited by Vaidya Yadavji Trikamji Acharya, Chaukhambha Surbharati Prakashan, Varanasi, reprint; 2008. p. 738, Sutra Sthana, Chapter 29, verse 88 ; p. 860.

6. Agnivesha, Charaka Samhita with Ayurveda Dipika commentary of Chakrapani, Edited by Vaidya Yadavji Trikamji Acharya, Chaukhambha Surbharati Prakashan, Varanasi, reprint; 2008. p. 738, Sutra Sthana, Chapter 29, verse 45 ; p. 830.

7. Agnivesha, Charaka Samhita with Ayurveda Dipika commentary of Chakrapani, Edited by Vaidya Yadavji Trikamji Acharya, Chaukhambha Surbharati Prakashan, Varanasi, reprint; 2013. p. 738, Sutra Sthana, Chapter 11, verse 55 ; p. 121.

8. Chakrapanidatta, Chakradatta, Edited by Dr. Indradev Tripathi, Chaukhambha Sanskrit Sansthan, Varanasi, edition; 2010. p. 523. Chapter 23, Verse 9, p. 199.

9. Chakrapanidatta, Chakradatta, Edited by Dr. Indradev Tripathi, Chaukhambha Sanskrit Sansthan, Varanasi, edition; 2010. p. 523, Chapter 25, verse 1- 3, p. 256.

\section{Cite this article as:}

Anisha M. S. et al. Role of Panchakarma in the management of Ankylosing Spondylitis: A Review. Int. J. Res. Ayurveda Pharm. 2020;11(4):215-218 $\quad$ http://dx.doi.org/10.7897/2277$\underline{4343.1104120}$ 